SALVATORE BELLA ${ }^{\mathrm{a}}$ - ROBERTO CATANIA ${ }^{\mathrm{a}}$ - COSIMO BAVIERA ${ }^{\mathrm{b} *}$

\title{
FIRST RECORD OF THE GENUS SERANGIUM BLACKBURN, 1889 (COLEOPTERA COCCINELLIDAE) IN ITALY
}

\begin{abstract}
a(CREA) Consiglio per la ricerca in agricoltura e l'analisi dell'economia agraria - Centro di Ricerca Olivicoltura, Frutticoltura e Agrumicoltura. Corso Savoia, 190, 95024 Acireale (CT), Italy salvatore.bella@crea.gov.it; robertocatania1995@gmail.com

${ }^{b}$ Department of Chemical, Biological, Pharmaceutical and Environmental Science, Messina University. Viale Stagno D'Alcontres, 31, 98164 Messina, Italy

*Corresponding Author: cbaviera@unime.it (C. Baviera)

Bella S., Catania R., Baviera C. - First record of the genus Serangium Blackburn, 1889 (Coleoptera, Coccinellidae) in Italy.

During a recent survey of ladybirds in a citrus orchard in Sicily, a specimen of the genus Serangium (Coleoptera, Coccinellidae) was found. This genus is recorded here for the first time from Italy. Species of this genus was used as an agent of biological control against aleyrodids, and stable populations were previously reported from Europe (France and Corsica) and in the Caucasian area. Literature of this genus recorded for Europe two species: Serangium montazerii Fürsch, 1995 and S. parcesetosum Sicard, 1929. The single specimen collected unable us to a specific attribution.
\end{abstract}

KEY WORDS: Ladybeetle; Serangium; Citrus; alien predator; Italy

\section{INTRODUCTION}

Numerous alien coccinellids introduced as classical agents of biological control have spread rapidly from countries where they were deliberately introduced to many other countries across Europe. Twelve species of alien coccinellids in Europe have been recorded as intentionally released as biological-control agents of pest insects, mainly in Mediterranean regions including France, Portugal and Italy. Furthermore, the commercial production of coccinellids by biological control companies led to a rapid increase in distribution in recent decades (ROY and MigEON, 2010; GERBER and SCHAFFNER, 2016; SOARES et al., 2018). To date, 11 species are effectively considered introduced in Europe like Chilocorus kuwanae Silvestri, 1909, recently synonymized with $C$. renipustulatus Scriba, 1791, described in Europe, Hyperaspis pantherina Fürsch, 1975, introduced only in the island of St. Helena, formely British island of the southern Atlantic Ocean, and Delphastus catalinae (Horn, 1895) that was recently confirmed as present in Italy (NUGNES et al., 2020) (Table 1).

The large genus, Serangium Blackburn, 1889, firstly described for Australia, to date contains more than 50 species and is distributed mainly in oriental regions (WANG et al., 2011) with several species in Africa and Australia (ŚLIPIŃSKI and BURCKHARDT, 2006; SZAWARYN and SZWEDO, 2018). Most species of rich extant faunas of Serangium occur in China (13 species) (WANG et al., 2011), and Australia (12 species) (ŚLIPIŃSKI and BURCKHARDT, 2006; ŚLIPIŃSKI, 2007), four species are recognized in India, Japan, Madagascar, and the Philippines (PoORANI, 2002; ŚLIPIŃSKI and BURCKHARDT, 2006). Serangium clauseni Chapin, 1940, was introduced to Cuba from Indonesia to control the citrus blackfly Aleurocanthus woglumi Ashby (CHAPIN, 1940; GORDON, 1977). Three fossil species described from Baltik amber, however, suggest that the modern distribution of the genus Serangium is only part of a broader former distribution (SZAWARYN and SZWEDO, 2018; SZAWARYN, 2019).

Like other Coccinellidae widely purchase for biological control, Serangium species used in biological control is also often mistakenly identified alternatively as $S$. montazerii Fürsch, 1995 or S. parcesetosum Sicard, 1929 (BOOTH and POLASZEK, 1996; DUVERGER, 1998; POORANI, 1998; BIEŃKOWSKI, 2018).

\section{MATERIALS AND METHODS}

Field studies were conducted in Sicily (Italy) at the experimental citrus field of CREA (Council for Agricultural Research and Economics), located in the suburban area of the town of Acireale (Catania province) (37 $37^{\prime}$ $\left.\mathrm{N}, 15^{\circ} 09^{\prime} \mathrm{E}\right)$ at 206 metres above sea level, in an orchard of 4 hectares, characterized by the presence of different species and variety of Citrus L. genus, with organic management.

A single specimen was collected from 12:00 to 16:00 with the beating technique and preserved in $70 \%$ alcohol in plastic vials. In the laboratory, it was prepared for identification and glued on label. The specimen was identified using the taxonomic keys by FÜRSCH (1995), POORANI (1998), and BIEŃKOWSKI (2018). The examined material was deposited in the collection of the authors. 
Table 1 - Coccinellids species introduced in Europe. With $(*)$ the species never, or not recently, recorded in Italy.

\begin{tabular}{|c|c|c|c|c|c|}
\hline $\begin{array}{l}\text { Biocontrol } \\
\text { target } \\
\text { group }\end{array}$ & $\begin{array}{l}\text { Biocontrol target } \\
\text { species }\end{array}$ & Species & $\begin{array}{l}\text { Introduction } \\
\text { year }\end{array}$ & $\begin{array}{l}\text { Source } \\
\text { country }\end{array}$ & $\begin{array}{l}\text { Introduction } \\
\text { country }\end{array}$ \\
\hline \multirow[t]{6}{*}{ Coccids } & $\begin{array}{l}\text { Icerya purchasi } \\
\text { Maskell, } 1878\end{array}$ & $\begin{array}{l}\text { Rodolia cardinalis } \\
\text { Mulsant, } 1850\end{array}$ & 1898 & Australia & Portugal \\
\hline & $\begin{array}{l}\text { Saissetia oleae } \\
\text { (Olivier, 1791) }\end{array}$ & $\begin{array}{l}\text { *Rhyzobius forestieri } \\
\text { (Mulsant, } 1853 \text { ) }\end{array}$ & 1980 & Australia & $\begin{array}{l}\text { Greece, Italy, } \\
\text { and France }\end{array}$ \\
\hline & & $\begin{array}{l}\text { Rhyzobius lophanthae } \\
\text { (Blaisdell, 1892) }\end{array}$ & 1973 & Australia & Europe \\
\hline & $\begin{array}{l}\text { Planococcus citri } \\
\text { Risso, } 1813\end{array}$ & $\begin{array}{l}\text { Cryptolaemus } \\
\text { montrouzieri Mulsant, } \\
1850\end{array}$ & 1907/1908 & Australia & Italy \\
\hline & Diaspididae & $\begin{array}{l}\text { *Chilocorus nigritus } \\
\text { (Fabricius, 1798) }\end{array}$ & 1985 & SE Asia & $\begin{array}{l}\text { France, Great } \\
\text { Britain }\end{array}$ \\
\hline & $\begin{array}{l}\text { P. citri, } \\
\text { Nipaecoccus vi- } \\
\text { ridis } \\
\text { (Newstead, 1894), } \\
\text { Pseudococcus vi- } \\
\text { burni (Signoret, } \\
1875 \text { ) }\end{array}$ & $\begin{array}{l}\text { *Nephus reunioni } \\
\text { (Fürsch, 1974) }\end{array}$ & 1974 & $\begin{array}{l}\text { Isle de La } \\
\text { Réunion }\end{array}$ & France \\
\hline \multirow[t]{2}{*}{ Aphids } & & $\begin{array}{l}\text { Harmonia axyridis } \\
\text { Pallas, } 1773\end{array}$ & 1980 & Asia & Portugal \\
\hline & & $\begin{array}{l}\text { *Hippodamia } \\
\text { convergens } \\
\text { Guérin-Méneville, } \\
1842\end{array}$ & $1990 / 2000$ & $\begin{array}{l}\text { North Amer- } \\
\text { ica }\end{array}$ & $\begin{array}{l}\text { Belgium, } \\
\text { Sweden, } \\
\text { Denmark, } \\
\text { Albania, } \\
\text { Czech Republic }\end{array}$ \\
\hline Psyllids & $\begin{array}{l}\text { Acizzia uncatoides } \\
\text { (Ferris \& Klyver, } \\
\text { 1932) }\end{array}$ & $\begin{array}{l}\text { *Harmonia conformis } \\
\text { (Boisduval, 1835) }\end{array}$ & 1998 & Australia & France \\
\hline \multirow[t]{2}{*}{ Aleyrodids } & $\begin{array}{l}\text { Dialeurodes citri } \\
\text { (Ashmead, 1885) }\end{array}$ & $\begin{array}{l}\text { Serangium } \\
\text { montazerii } \\
\text { Fürsch, } 1995 \text { / Seran- } \\
\text { gium parcesetosum } \text { Si- } \\
\text { card, } 1929\end{array}$ & 1985 & Iran/India & France \\
\hline & & $\begin{array}{l}\text { Delphastus catalinae } \\
\text { (Horn, 1895) }\end{array}$ & 2020 & $\begin{array}{l}\text { Tropical } \\
\text { America }\end{array}$ & Italy \\
\hline
\end{tabular}

\section{NEW RECORD}

Subfamily Microweiseinae Leng, 1920

Tribe Serangiini Blackwelder, 1945

\section{Serangium Blackburn, 1889}

GENERAL DISTRIBUTION: Africa (Madagascar), Australia, Palaearctic (especially in the Oriental regions).

EXAMINED MATERIAL: (Fig. I) Sicily - Catania (province), Acireale, 15.IX.2019, 10 , on a mandarin tree, Citrus reticulata Blanco, infested by Aleurothrixus floccosus (Maskell, 1895), S. Bella leg., C. Baviera det..

\section{SERANGIUM SPECIES REPORTED FROM EUROPE:}

Serangium parcesetosum Sicard, 1929
This species was described from Southern India, by SICARD (1929), in original description there are no drawings nor description of genitalia. Its color is reported as fawn and elytra described as "not punctured even in lateral". S. parcesetosum was introduced into the Caucasian Black Sea coast of Georgia in 1973 (TIMOFEEVA and NHUAN, 1978) and thereafter to the south of France and Corsica from Georgia in 1985 for biological control of Aleyrodidae (ANTADZE and TIMOFEEVA, 1975; TIMOFEEVA and NHUAN, 1978; MALAUSA et al., 1988). This species also was found in the East Black Sea coast of Turkey and introduced into the East Mediterranean region of the country in 1990 (YIĞIT, 1992; YIĞIT and CANHILLAL, 2005). In Turkey, it has successfully adapted in areas where citrus are grown (ULUSOY et al., 1996; UYGUN et al., 1997). In India this species was reported to be a very host specific on the cotton whitefly, Bemisia tabaci (Gennadius, 1889) (KAPADIA and PURI, 1992) and on the sugarcane whitefly, Aleurolobus barodensis (Maskell, 1895) 


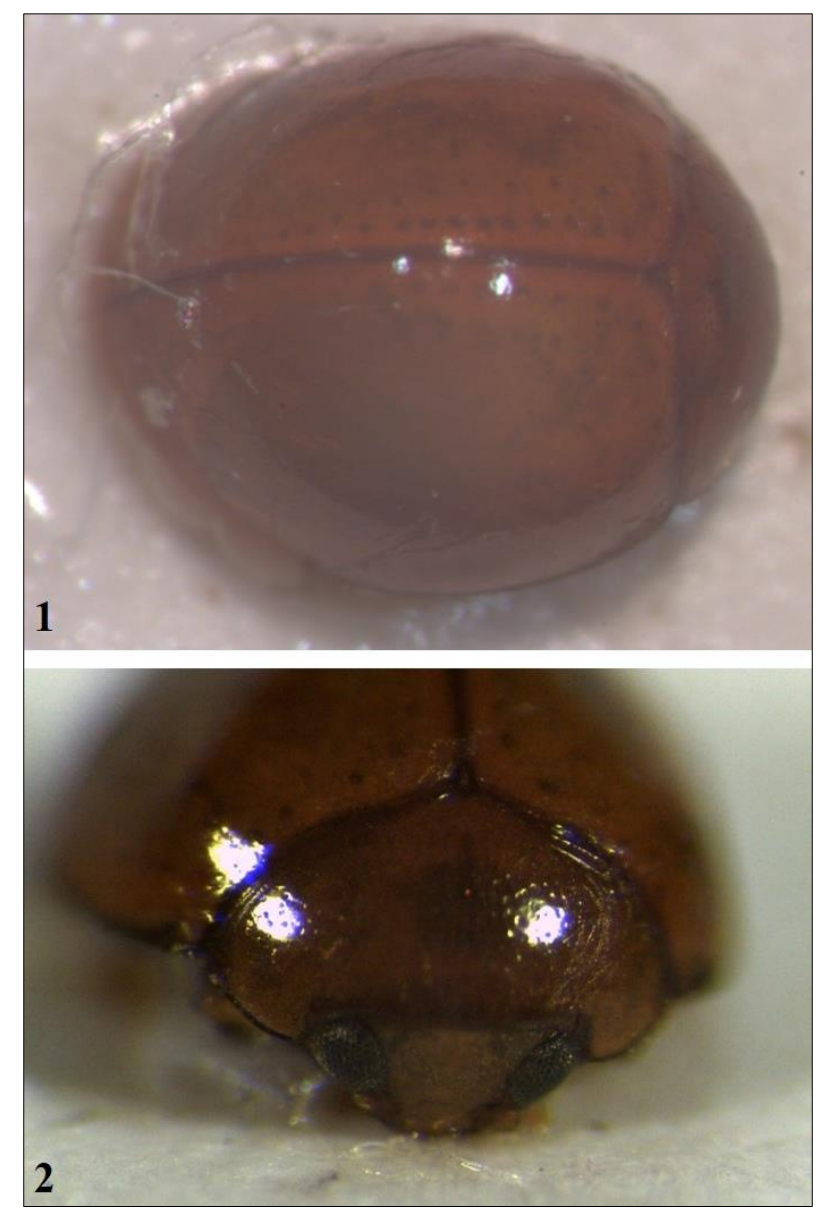

Fig. I - Serangium montazerii Fürsch. (1-2): Male.Sicily, Acireale, 15.IX.2019.

(SHAH et al., 1986; PATEL et al., 1996). Many other species of whiteflies were recorded as prey of this ladybird like Aleurocanthus woglumi Ashby, 1915, Aleurolobus barodensis, Aleurothrixus floccosus, Bemisia afer (Priesner and Hosny, 1934), Parabemisia myricae (Kuwana, 1927), and Paraleyrodes minei Iaccarino, 1990 (EvANS, 2007). S. parcesetosum was found very common in citrus groove usually followed the whiteflies populations trends as observed in two orchards in Turkey (YIĞIT et al., 2003).

\section{Serangium montazerii Fürsch, 1995}

This species was described from specimens collected in Iran on Salvia L., and Citrus plants (Fürsch, 1995). In original description male genitalia was reported and the colour is recorded as yellowish-brown and elytra was described as "bearing a row of brown dots at both sides of the suture, separated from it by about 8 times their diameter". Like $S$. parcesetosum this species has been collected on citrus, olive, pomegranate, and sage; it is a predator of the psyllid Euphyllura olivina (Costa, 1839) and of the aleyrodid species Dialeurodes citri (Ashmead, 1885), and Bemisia tabaci (HAJIZADEH et al., 2003; MODDARRES-AWAL, 2012). Some aleyrodid known as prey of $S$. parcesetosum now were considered prey of $S$. montazerii (Aleurocanthus woglumi, Aleurolobus barodensis, Aleurothrixus floccosus, Bemisia afer, Parabemisia myricae, and Paraleyrodes minei) (EVANS, 2007).

Unfortunately, these two species was often confused one with the other. In 1996 BoOTH and POLASZEK, reported that Serangium montazerii and S. parcesetosum are very similar and can be differentiated mainly by genitalia and also by few morphological characters. They reported, for the first time, the male genitalia of the two species, but there are some problems to be consider: 1) they designated a female lectotype of $S$. parcesetosum by a female paratype preserved in British Museum of Natural History, but they didn't explained the origin of the male genitalia reported by them; 2) they re-drew the male genitalia of a paratype of $S$. montazerii, but it seem quite different that the one of the holotype of FÜRSCH (1995); 3) S. montazerii is "considered native from India and Pakistan" and considered as only "recently recorded in Iran and Syria". The authors considered that this species, and not $S$. parcesetosum, as introduced into the Caucasian Black Sea coast of Georgia in 1973 and from there to France and Corsica (MALAUSA et al., 1988) and after in Israel from France (HALPERIN et al., 1995). Furthermore, BOOTH and POLASZEK (1996), don't considered elytral punctuation, different in the two species in the original descriptions, with the punctations more prominent in $S$. montazerii.

POORANI (1998) follows BOOTH and POLASZEK (1996) considered $S$. montazerii and $S$. parcesetosum as very similar species both present in India (the first at North and the second at South) reporting the genitalia and morphological characters of the two species, but without give the localities of the examined specimens.

DUVERGER (1998) follows BOOTH and POLASZEK (1996), replaces $S$. parcesetosum with $S$. montazerii as present in France and Corse.

Subsequently, $S$. parcesetosum was rehabilitated for France and Corse by COUTANCEAU (2006) who studied the specimens collected from 1986 to 2000 in Corse.

Serangium listed by the "EPPO list of biological control agents widely used in the EPPO Region" (EPPO, 2020) is recorded as $S$. parcesetosum. It was considered as introduced in Europe in 1985 for the biological control of Dialeurodes citri, and Bemisia tabaci (Hemiptera, Aleyrodidae) (ANTADZE and TIMOFEEVA, 1975, 1976; TIMOFEEVA and NHUAN, 1978; MALAUSA et al., 2008; FOTUKKIAII et al., 2013; ORLOVA-BIENKOWSKAJA and BIEŃKOWSKI, 2017; SOARES et al., 2018).

If we considered the elytra punctuation as absent in $S$. parcesetosum and constituted by a row of brown dots at both sides of the suture, separated from it by about 8 times their diameter in $S$. montazerii, the two species seems morphologically very different in elytral sculpture, moreover S. montazerii was described on specimens from Iran and there are no published data about specimens collected in northern India, or Pakistan.

Serangium purchased for biological control probably belonged to at least two different species: one near to $S$. parcesetosum. These two species was very probably erroneously linked the released and established in the Caucasian regions (Abkhazia, Azerbaijan, and Georgia), in 


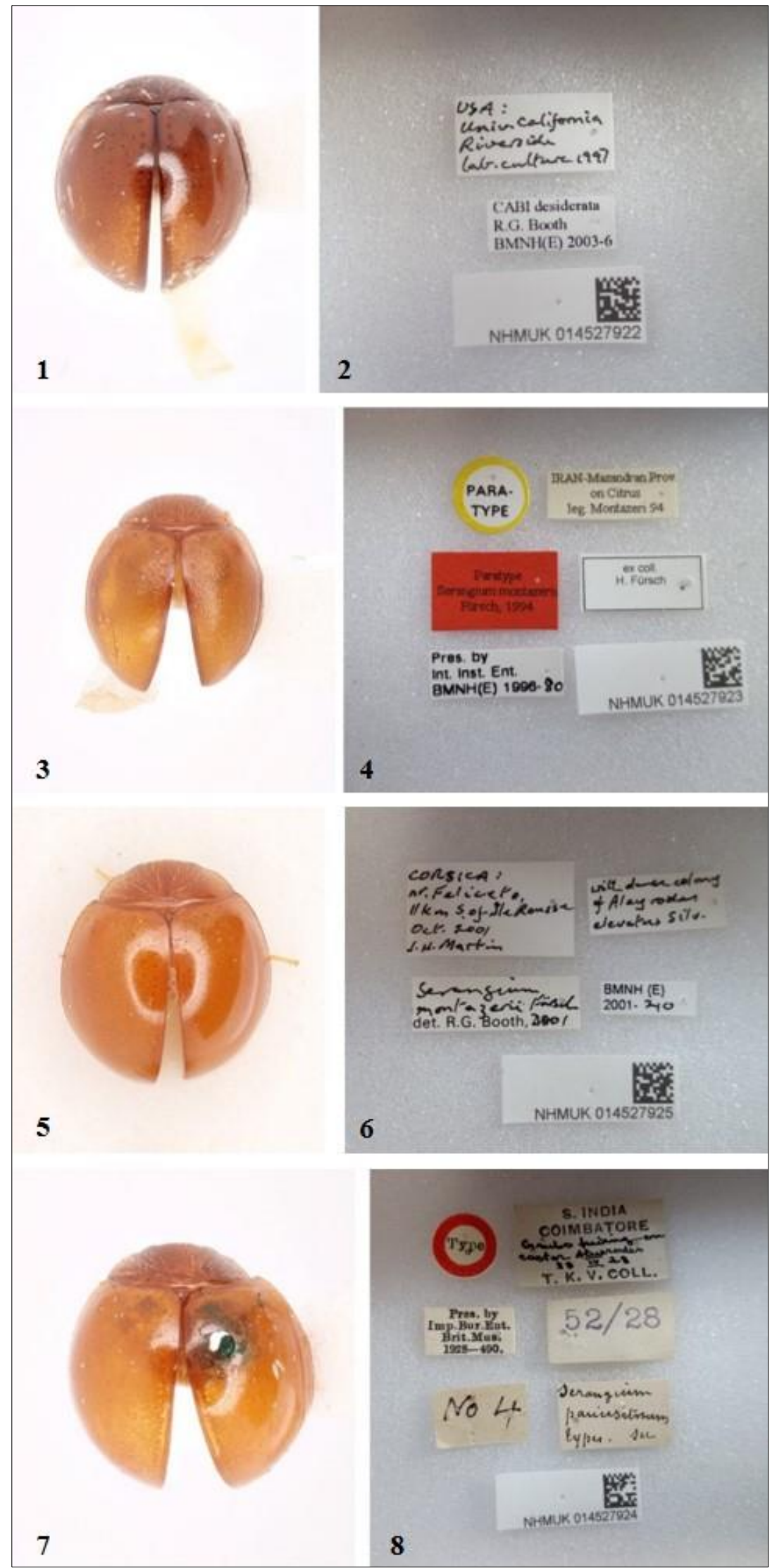

Fig. II - Photos from Natural History Museum, London: (1-2) Serangium montazerii Fürsch. Non-type USA; (3-4) S. montazerii Fürsch. Paratype Iran; (5-6) S. montazerii Fürsch. Non-type Corsica; (7-8) S. parcesetosum Sicard. Paratype India. 
southern Russia (Sochi) and also in France, Turkey, Israel, and Syria (IZEVSKY, 1990; POORANI, 1998; KOVÁr̆, 2007; MODDARRES-AWAL, 2012; BIRANVAND et al., 2016; BIEŃKOWSKI and ORLOVA-BIENKOWSKAJA, 2020).

The specimen collected in Sicily seem very similar, by elytra punctuation, to the one figured from Sochi National Park (Western Caucasus at the Black Sea Shore), which seems more similar to $S$. parcesetosum than to $S$. montazerii for the presence of two rows of large punctures along elytral suture (ORLOVA-BIENKOWSKAJA and BIEŃKOWSKI, 2017). These specimens seem to be far from another specimen figured from Palestine which seems very near to $S$. parcesetosum for the absence of large punctuation on elytra (NAJAJRAH et al., 2019).

Specimens actually preserved in Natural History $\mathrm{Mu}-$ seum, London allows to identify the Sicilian specimens very similar to a singleton specimen from a laboratory population came from USA (Fig. II, 1-2) identified as " $S$. montazerii", but very different from the paratype specimen of this species from Iran and from the non-type specimen from Corsica, which show elytra dull and rusty without dots (Fig. II, 3-6). The paratype specimen from India attribute to $S$. parcesetosum, preserved in the same collection have a row of big punctures at both sides of the elytral suture (Fig. II, 7-8). Furthermore, the paratype specimen from Iran (Fig. III) preserved in the Zoologische Staatssammlung München, shows a single row of big punctures at both sides of the suture.

\section{CONCLUDING REMARKS}

The presence of a species of the Oriental coccinellid Serangium is documented for the first time in Italy. A single specimen was collected in September 2019, in a Sicilian citrus orchard with organic management. In Europe, $S$. montazerii and/or $S$. parcesetosum were considered to be released to control Aleyrodidae on citrus trees in France and Corsica, establishing and continuing to spread spontaneously. The collected specimens seem didn't belonged to no ones of this two species, even if more similar to $S$. parcesetosum while $S$. montazerii seems very probably not present in Europe.

Climatic areas of possible acclimatization for $\mathrm{Se}$ rangium spp. are numerous along the Italian peninsula and in Sicily, and after this first discovery further investigations are recommended for monitoring the diffusion of this allochthonous predator. Even if the larvae and adults of $S$. parcesetosum tended to avoid Bemisia tabaci pupae parasitized by Eretmocerus mundus Mercet, 1931 (Hymenoptera, Aphelinidae) (AL - ZYOUD, 2007), more studies will be needed to verify the real environmental interactions of this new coccinellid species with indigenous ones in Sicily and the effective interaction with other predators and parasitoids (CIACCIA et al., 2019; BELLA et al., 2021; RONDONI et al., 2021) already present in citrus agroecosystems (BELLA, 2020).

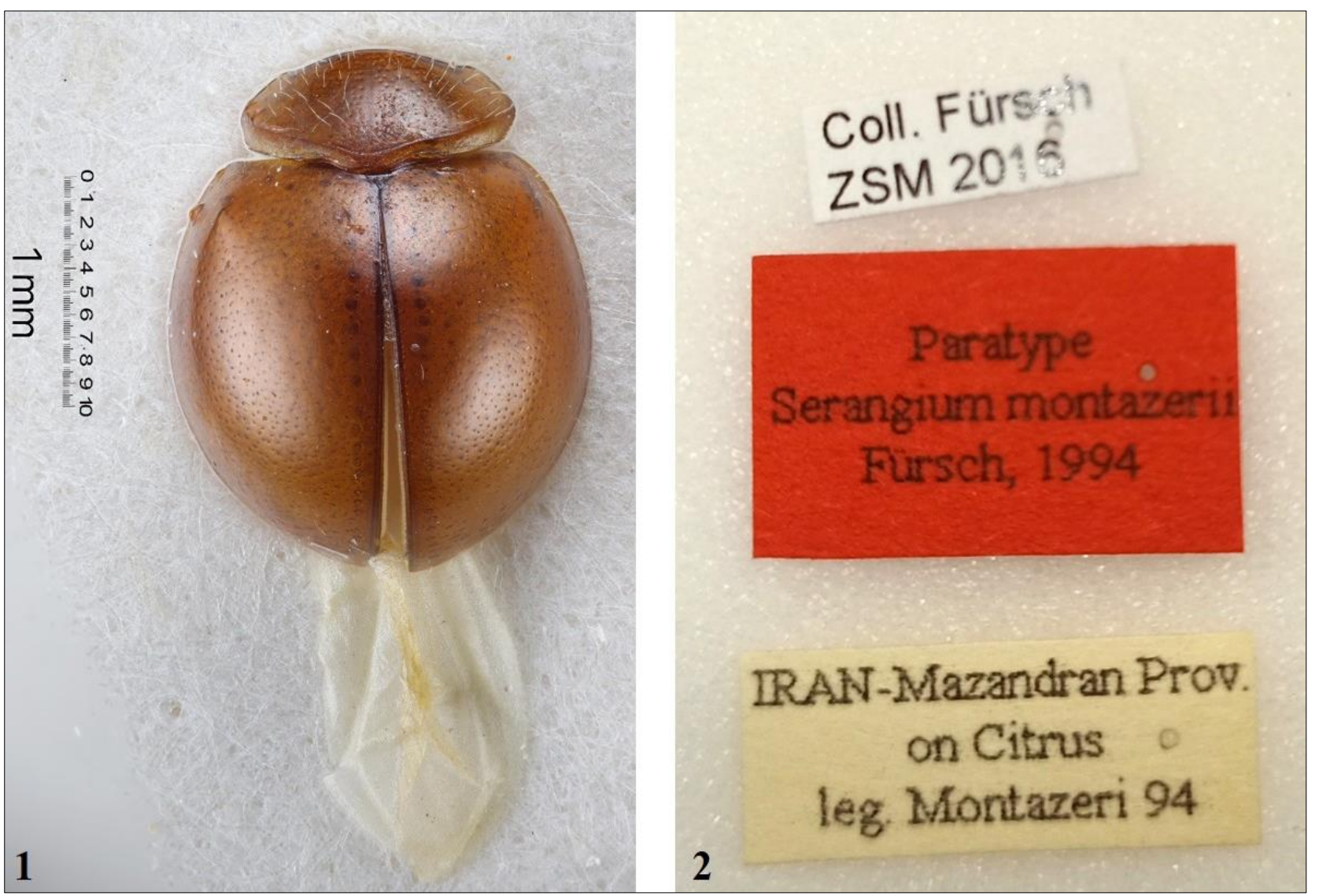

Fig. III - Serangium montazerii Fürsch. Paratype Iran, (1-2). Photos from Zoologische Staatssammlung München 


\section{ACKNOWLEDGEMENTS}

We express our gratitude to Keita Matsumoto (Natural History Museum, London) and to Michael Balke (Zoologische Staatssammlung München) for giving us photos of $S$. montazerii and $S$. parcesetosum preserved in the Museums.

\section{REFERENCES}

AL - ZYOUD F.A., 2007 - Prey species preferences of the predator Serangium parcesetosum Sicard (Col., Coccinellidae) and its interaction with another natural enemy. - Pakistan J. of Biological Sciences, 10: 2159 $-2165$.

ANTADZE A.I., TIMOFEEVA T.V., 1975 - An effective predator of Citrus Whitefly. - Subtropicheskie Kul'tury, 3: 80-81.

ANTADZE A.I., TIMOFEEVA T.V., 1976 - A predator of the Citrus whitefly. - Zashchita Rastenii, 10: 46.

BELlA S., 2020 - The Nearctic bug Zelus renardii (Kolenati) (Hemiptera, Reduviidae) in Northern Italy and Sicily. - Redia, 103: 87-88. https://doi.org/10.19263/ REDIA-103.20.14.

BELla S., CATANIA R., BAVIERA C., 2021 - First data on establishment and population dynamics of the Neotropical Delphastus catalinae (Horn) in Europe (Coleoptera, Coccinellidae). (In prep)

BIEŃKOWSKI A.O., 2018 - Key for identification of the ladybirds (Coleoptera: Coccinellidae) of European Russia and the Russian Caucasus (native and alien species). - Zootaxa, 4472 (2): 233-260. https://doi. org/10.11646/zootaxa.4472.2.2.

BIEŃKOWSKI A.O., ORLOVA-BIENKOWSKAJA M.J., 2020 - History of the biodiversity of Ladybirds (Coccinellidae) at the Black Sea coast of the Russian Caucasus in the last 120 years. Does the landscape transformation and establishment of Harmonia axyridis have an impact? - Insects, 11 (11): 824. https://doi.org/ 10.3390/insects 11110824 .

Biranvand A., NedVĚD O., TOMASZEWSKa W., CANEPARI C., SHAKARAMI J., FEKRAT L., KHORMIZI M.Z., 2016 - An annotated checklist of Microweiseinae and Sticholotidini of Iran (Coleoptera, Coccinellidae). - ZooKeys, 587: 37-48. https://doi. org/10.3897/zookeys.587.8056.

Ciaccia C., La Torre A., Ferlito F., Testani E., Battaglia V., Salvati L., Roccuzzo G., 2019-Agroecological Practices and Agrobiodiversity: A case study on Organic Orange in Southern Italy. - Agronomy, 9 (85): 2-13. https://doi:10.3390/agronomy9020085.

COUTANCEAU J.P., 2006 - Serangium parcesetosum Sicard 1929 en Corse: réhabilitation et nouvelles localités (Col. Coccinellidae). - Le Coléoptériste, 9 (3): 180.

DUVERGER C., 1998 - Serangium montazerii Fürsch 1995, (Coléoptère Coccinellidae) introduit en France et Corse sous le nom de Serangium parcesetosum $\mathrm{Si}$ card 1929. - Bulletin de la Société linnéenne de Bordeaux, 26 (2): 97-98.
EPPO/OEPP, 2020 - List of biological control agents widely used in the EPPO region. - Bulletin de l'Organisation Européenne et Méditerranéenne pour la Protection des Plantes, 32: 447-461.

Evans G.A., 2007 - The Whiteflies (Hemiptera: Aleyrodidae) of the world and their host plants and natural enemies. - Usda, Animal Plant Health Inspection Service (Aphis).

FotUKKIAII S.M., SAHRAGARD A., HALAJISANI M.F. 2013 - Comparing demographic parameters of Serangium montazerii (Coleoptera: Coccinellidae) on citrus whitefly, Dialeurodes citri (Hemiptera: Aleyrodidae) fed on two host plants. - Biology, 2: 5161.

FÜRSCH H., 1995 - A new Serangium species from Iran (Coleoptera: Coccinellidae). - Nachrichtenblatt der Bayerischen Entomologen, 44: 20-22.

GERBER E., SCHAFFNER U., 2016 - Review of Invertebrate Biological Control Agents Introduced into Europe. CABI.

HAJIZADEH J., JALILI SENDI J., PEYROVI H., 2003 - Introducing a part of the coccinellids (Col., Coccinellidae) fauna of Guilan province. - J. of Agricultural Sciences and Natural Resources, 9: 99-111.

HALPERIN J., MERKL O., KeHAT M., 1995 - An annotated list of the Coccinellidae (Coleoptera) of Israel and adjacent areas. - Phytoparasitica, 23 (2), 127-137. https://doi.org/10.1007/BF02980972

IZEVSKY S.S., 1990 - Introduction and application of entomophages. Moscow: Agropromizdat, 223 pp. [In Russian]

KovÁŘ I., 2007 - Coccinellidae. In: LÖBL I., SMETANA A. (Eds.): Catalogue of Palaearctic Coleoptera. Vol. 4. Stenstrup: Apollo Books. 568-631.

LEGASPI J.C., LEGASPI B.C., MEAGHER R.L., CIOMPERLIK M.A.., 1996 - Evaluation of Serangium parcesetosum (Col., Coccinellidae) as a biological control agent of the silverleaf whitefly (Hom., Aleyrodidae). Environmental Entomology, 25: 1421-1427.

MAlausa J.C., FRANCO E., BRUN P., 1988 - Acclimatation sur la Côte d'Azur et en Corse de S. montazerii (Col., Coccinellidae) prédateur de l'Aleurode des citrus, Dialeurodes citri (Hom.: Aleyrodidae). - Entomophaga, 33: 517-519.

Malausa J.C., RABASSE J.M., KREITER P., 2008 - Les insectes entomophages d'intérêt agricole acclimatés en France métropolitaine depuis le début du 20ème siècle. - Bulletin de l'Organisation européenne et méditerranéenne pour la Protection des plantes, 38: 136146.

MODDARRES-AWAL M., 2012 - List of agricultural pests and their natural enemies in Iran. Fourth print, Third edition. Ferdowsi University Press, Mashhad, Iran, $759 \mathrm{pp}$.

NAJAJRAH M. H., SWAILEH K.M., QUMSIYEH M.B., 2019 - Systematic list, geographic distribution and ecological significance of lady beetles (Coleoptera: Coccinellidae) from the West Bank (Central Palestine). Zootaxa, 4664 (1): 001-046

Nugnes F., LAUdonia S., Jesu G., JANSEN M.G.M., BERNARDO U., PORCELLI F., 2020 - Aleurocanthus 
spiniferus (Hemiptera: Aleyrodidae) in some European countries: diffusion, hosts, molecular characterization, and natural enemies. - Insects, 11: 1-14. https://doi:10.3390/insects11010042.

ORLOVA-BIENKOWSKAJA M.J., BIEŃKOWSKI A.O., 2017 - Alien Coccinellidae in Sochi National Park and its vicinity. - Nature Conservation Res., 2: 96-101.

Patel C.B., Rai A.B., PAstagia J.J., PATEl H.M., PATEL M.B., 1996 - Biology and predator potential of Serangium parcesetosum Sicard (Col., Coccinellidae) of sugarcane white-fly (Aleurolobus barodensis Mask.). - GAU Research Journal, 21: 56-60.

POORANI J., 1998 - A new species of Serangium Blackburn (Coleoptera: CoccineIIidae), with a key to species, from India. - J. of Biological Control, 12 (1): 5561.

POORANI J., 2002 - An annotated checklist of the Coccinellidae (Coleoptera) (excluding Epilachninae) of the Indian subregion oriental. - Insects, 36 (1): 307 383.

Rondoni G., Borges I., Collatz J., Conti E., CosTAMAGNA A.C., DUMONT F., Evans E.W., GreZ A.A., Howe A.G., LuCAS E., Maisonhaute J.-E., SOARES A.O., ZAVIEZO T., COCK M.J.W., $2021-E x$ otic ladybirds for biological control of herbivorous insects - a review. - Entomologia Experimentalis et Applicata, 169: 6-27.

Roy H., MigeOn A., 2010 - Ladybeetles (Coccinellidae). Chapter 8.4. In: Roques A et al. (Eds) Alien terrestrial arthropods of Europe. - BioRisk, 4 (1): 293-313. https://doi: 10.3897/biorisk.4.49.

SHAH F.H., SHAH W.H., YASIN M., ABDUllaH M., 1986 - Detoxification of commercially produced cottonseed meal. - Pakistan J. Scientific and Ind. Res., 29 (5): 380-382.

SICARD A., 1929 - Descriptions de quelques especes nouvelles de Coccinellides de la faunae Indo-Malaise. - Annals and magazine of Natural History, 3: 179-184.

SoAres A., HonĚK A., MARTinKova Z., Brown P.M.J., Borges I., 2018 - Can Native Geographical Range, Dispersal Ability and Development Rates Predict the successful Establishment of Alien Ladybird (Coleop tera:Coccinellidae) Species in Europe? - Frontiers in Ecology Evolution, 6: 57. https://doi: 10.3389/fevo. 2018.00057.
SZAWARYN K., 2019 - Unexpected diversity of whitefly predators in Eocene Baltic amber-new fossil Serangium species (Coleoptera: Coccinellidae). Zootaxa, 4571 (2): 270-276.

SZAWARYN K., SZWEDO J., 2018 - Have ladybird beetles and whiteflies co-existed for at least 40 mya? - Palaontologische Zeitschrift, 11 pp. https://doi:10.1007/ s12542-018-0409-5.

TIMOFEEVA T.V., NHUAN H.D., 1978 - Morphological and biological characteristics of Indian lady-bird Serangium parcesetosum Sicard (Coleoptera, Coccinellidae), predator of the citrus whitefly in Adzharia. - Revue d'Entomologie de l'URSS, 57 (2): 302308. [in Russian]

UluSOY M.R., UYGUN N., KERSTING U., KARACA I., SATAR S., 1996 - Present status of citrus whiteflies (Homoptera: Aleyrodidae) in Turkey and their control. J. Plant Dis. Protection, 103: 397-402.

UYGUN N., UlusOY M.R., KARACA I., Kersting U., 1997 - Approaches to biological control of Dialeurodes citri (Ashmead) in Turkey. - IOBC/WPRS Bulletin, 20: 52-62.

VATANSEVER G., ULUSOY M.R., BAKIRCIOĞLU ERKILIÇ L., 2003 - Improving the mass rearing possibilities of Serangium montazerii Fürsch (Coleoptera: Coccinellidae) on different host plants of Bemisia tabaci (Genn.) (Homoptera: Aleyrodidae). - Turkish J. of Agriculture and Forestry, 27: 175-181.

YIĞIT A., 1992 - Serangium parcesetosum Sicard (Coleóptera: Coccinellidae): New record as a citrus whitefly predatory lady beetle in Turkey. - Türkish Entomol. Dergisi, 16: 163-167.

YıĞIT A., CANHİlal R., EKMEKCI U. 2003 - Seasonal Population Fluctuations of Serangium parcesetosum (Coleoptera: Coccinellidae), a Predator of Citrus Whitefly, Dialeurodes citri (Homoptera: Aleyrodidae) in Turkey's Eastern Mediterranean Citrus Groves. Environmental Entomology, 32 (5): 1105-1114.

YIĞIT A., CANHİlal R., 2005 - Establishment and dispersal of Serangium parcesetosum Sicard (Coleoptera, Coccinellidae), a predatory beetle of citrus whitefly, Dialeurodes citri Ashm. (Homoptera, Aleyrodidae) in the East Mediterranean region of Turkey. - J. of Plant Diseases and Protection, 112 (3): 268-275. 